Article

\title{
Temporal Dependency of Yield and Quality Estimation through Spectral Vegetation Indices in Pear Orchards
}

\author{
Jonathan Van Beek ${ }^{1}$, , Laurent Tits ${ }^{1}$, Ben Somers ${ }^{2}$, Tom Deckers ${ }^{3}$, Wim Verjans ${ }^{3}$, \\ Dany Bylemans ${ }^{1,3}$, Pieter Janssens ${ }^{4}$ and Pol Coppin ${ }^{1}$
}

1 KU Leuven, Department of Biosystems, Division of Crop Biotechnics, Willem de Croylaan 34, BE-3001 Leuven, Belgium; E-Mails: laurent.tits@biw.kuleuven.be (L.T.); dany.bylemans@pcfruit.be (D.B.); pol.coppin@biw.kuleuven.be (P.C.)

2 KU Leuven, Department of Earth and Environmental Sciences, Division of Forest, Nature and Landscape Research, Celestijnenlaan 200E, BE-3001 Leuven, Belgium;

E-Mail: ben.somers@ees.kuleuven.be

3 Pcfruit research station, Fruittuinweg 1, BE-3800 Sint-Truiden, Belgium; E-Mails: tom.deckers@pcfruit.be (T.D.); wim.verjans@ @cfruit.be (W.V.)

4 Soil Service of Belgium, Willem de Croylaan 48, BE-3001 Leuven, Belgium; E-Mail: pjanssens@bdb.be

* Author to whom correspondence should be addressed; E-Mail: jonathan.vanbeek@biw.kuleuven.be; Tel.: +32-16-328-146; Fax: +32-16-322-966.

Academic Editors: Tao Cheng, Clement Atzberger and Prasad S. Thenkabail

Received: 23 March 2015 / Accepted: 28 July 2015 / Published: 4 August 2015

\begin{abstract}
Yield and quality estimations provide vital information to fruit growers, yet require accurate monitoring throughout the growing season. To this end, the temporal dependency of fruit yield and quality estimations through spectral vegetation indices was investigated in irrigated and rainfed pear orchards. Both orchards were monitored throughout three consecutive growing seasons, including spectral measurements (i.e., hyperspectral canopy reflectance measurements) as well as yield determination (i.e., total yield and number of fruits per tree) and quality assessment (i.e., fruit firmness, total soluble solids and fruit color). The results illustrated a clear association between spectral vegetation indices and both fruit yield and fruit quality $(|\mathrm{r}|>0.75 ; p<0.001)$. However, the correlations between vegetation indices and production variables varied throughout the growing season, depending on the phenological stage of fruit development. In the irrigated orchard, index values showed a strong association with production variables near time of
\end{abstract}


harvest $(|\mathrm{r}|>0.6 ; p<0.001)$, while in the rainfed orchard, index values acquired during vegetative growth periods presented stronger correlations with fruit parameters $(|r|>0.6$; $p<0.001$ ). The improved planning of remote sensing missions during (rainfed orchards) and after (irrigated orchards) vegetative growth periods could enable growers to more accurately predict production outcomes and improve the production process.

Keywords: temporal dependence; fruit yield and quality estimation; pyrus communis "conference"; hyperspectral remote sensing

\section{Introduction}

In capital-intensive horticultural cropping systems, estimating production or the production potential is essential in scheduling management decisions (i.e., fruit thinning, harvest, etc.). One of the difficulties, however, is the variable influence of contributing factors on fruit yield and quality during different phenological stages (review by [1]). For example, water deficiencies during Stage I or III of fruit development — cell division and fruit thickening stage — will decrease yield, while a moderate deficiency during Stage II of fruit development-cell expansion-has no effect on yield [2,3]. Traditional in situ measurements of production variables and biophysical variables are time consuming and labor intensive. This results in limited samples and repetitions, which are insufficient to account for the high spatial and temporal variability within and between orchards [4,5]. It is yet well acknowledged that remote sensing can provide non-destructive, time efficient and cost beneficial alternatives for horticulture [6-8].

The application of remote sensing for crop yield estimation was mostly developed for annual crops [9-11]. For perennials, the estimation of production properties through remote sensing was previously investigated for different fruit crops, such as citrus [12,13], apple [5,14], peach [15], olives [15] and grapevines [16]. In these studies, the focus lay mostly on the estimation of overall yield, as higher yields were the main interest. In recent years, however, the focus in pear production systems shifted more towards quality-related production characteristics, because of the willingness to pay more for better quality fruit [17]. Although the research on quality estimation was primarily done post-harvest through proximal sensing [18], several studies have estimated qualitative traits through remote sensing imagery at time of harvest $[12,15,19]$ or during specific periods within the growing season $[13,16]$. However, these studies were mostly based on single-image acquisitions and did not account for the variable nature of the growing season. Because the relationship between spectral measurements and production variables could vary between different phenological stages [13], the use of different vegetation indices during different growing stages would be required [20]. To optimize the scheduling of remote sensing missions and to monitor the production potential throughout the growing season, the temporal profile of the association between spectral information and production variables requires further investigation.

The primary goal of this study was to investigate the potential of remote sensing technology for estimating both production quality and quantity in pear orchards. The temporal variability of this 
relationship throughout the growing season-i.e., optimal moments for yield and fruit quality monitoring - was explored for two orchards with different management and irrigation setups.

\section{Materials and Methods}

\subsection{Study Area}

The irrigated orchard, planted with Conference pear trees (Pyrus communis L. cv. "Conference") on Quince C rootstock, was situated in Bierbeek, Belgium $\left(50^{\circ} 49^{\prime} 34.59^{\prime \prime} \mathrm{N}, 4^{\circ} 47^{\prime} 42.83^{\prime \prime} \mathrm{E}\right)$. The $2.5 \mathrm{~m}$ high trees were planted in a 3.5 by 1 meter grid in 2000 and were trained in a V-system with four fruiting branches on one central stem [21]. A side view of the irrigated orchard is shown in Figure 1A. The trees received $100 \%$ of the reference evapotranspiration (ETo) [22] throughout the growing season, except during Stage II of fruit development, characterized mostly by vegetative growth [3,23]. During this period, two irrigation treatments were applied. More information on the irrigation treatment can be found in Van Beek et al. [24]. Four plots of four trees each were selected on fixed intervals $( \pm 30 \mathrm{~m})$ within four rows and monitored throughout the 2011, 2012 and 2013 growing seasons (48 plots).

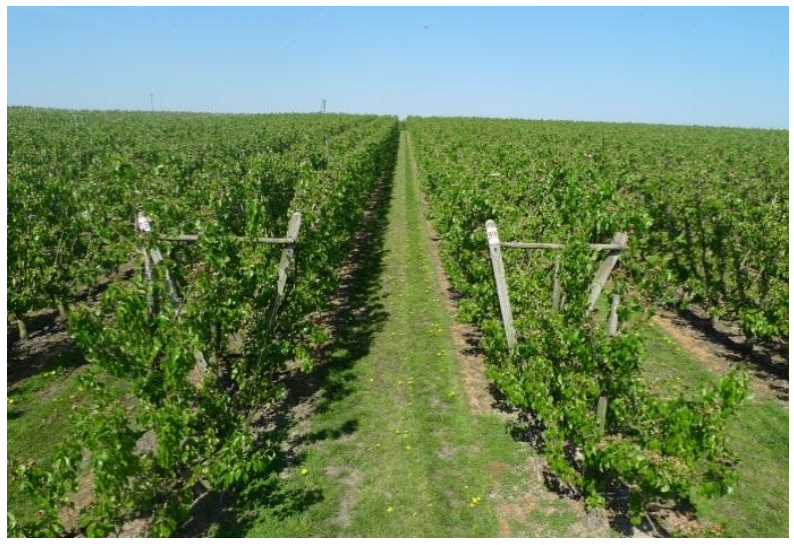

(A)

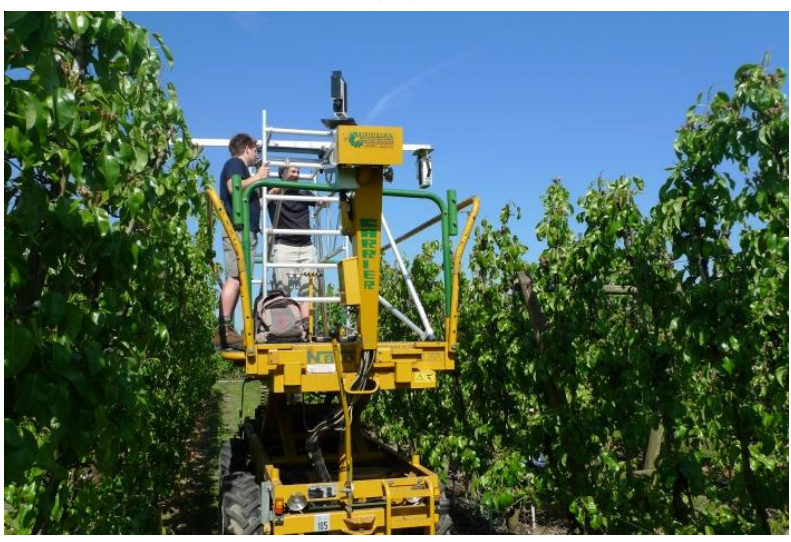

(C)

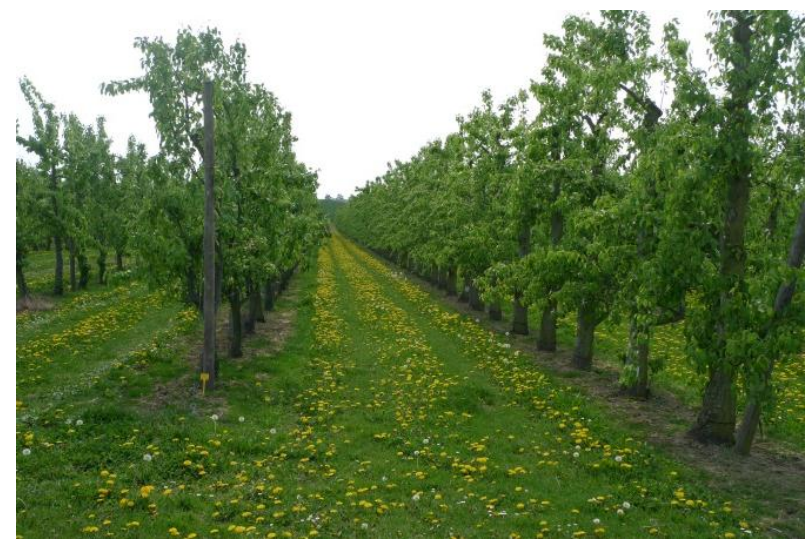

(B)

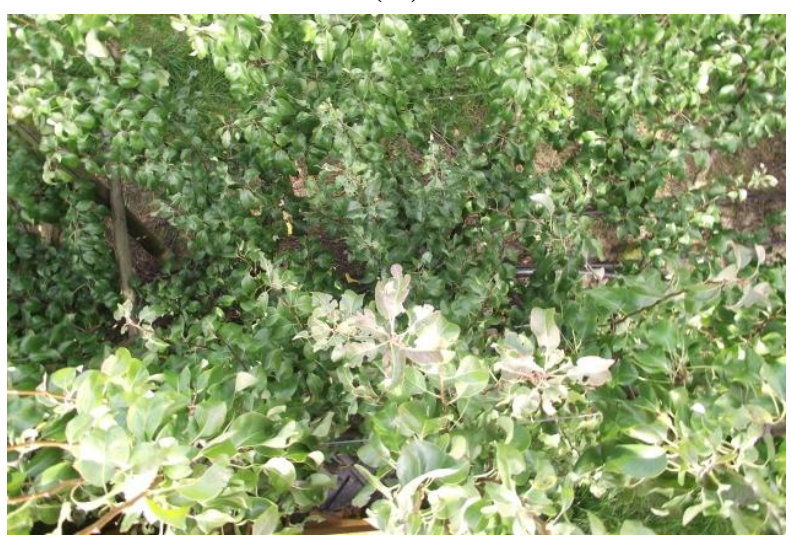

(D)

Figure 1. Side view of V-shaped training system used in the irrigated orchard (A); side view of Spindle bush system in the rainfed orchard (B); spectral measurement setup (C); Top view of V-system in the irrigated orchard (D). 
The non-irrigated or rainfed orchard, situated in Kerkom, Belgium (50 46'24.25"N, 5 09'27.05"E), was planted with Conference pear trees on Quince A rootstock in 2000 . The $3.5 \mathrm{~m}$ high trees were planted in a 3.75 by $1.75 \mathrm{~m}$ grid and trained in a Spindle bush system [21]. A side view of the rainfed orchard is shown in Figure 1B. Two adjacent rows were selected and each row was divided into eight plots of four trees. Root pruning was applied on one side of the stem in the beginning of the growing season. This treatment was alternated between sides of the stem for subsequent growing seasons. In each row, a root-pruned plot was alternated with a non-treated plot. In 2011, only one row was monitored in the rainfed orchard (40 plots).

\subsection{Ground Measurements}

\subsubsection{Fruit Yield and Quality}

During the 2011, 2012 and 2013 growing seasons, harvest was carried out on Day of Year (DOY) 230 (243), 249 (250) and 253 (261) in the irrigated orchard (rainfed orchard), respectively. Total yield and number of fruits was determined on four trees per plot and averaged.

Fruit quality was determined three months after harvest with storage at $-0.5{ }^{\circ} \mathrm{C}$ in a cooling cell without controlled atmosphere. The green background color was determined with a Konia Minolta chromameter through chroma and hue values at the shadow side of the fruits (i.e., the side that faces away from the sun) [25]. Chroma indicates the degree of departure from gray or white towards the pure color and is a measure of brightness, while hue angle quantifies color from red-green $\left(0^{\circ}-180^{\circ}\right)$. Fruit firmness was measured with a penetrometer $\left(0.5 \mathrm{~cm}^{2}\right.$ cylinder $)$ after removal of the skin, while Total Soluble Solids (TSS, ${ }^{\circ}$ brix) was determined with a hand-held refractometer. All fruit quality variables were determined on 60 fruits per plot and averaged per plot.

\subsubsection{Spectral Measurements}

Throughout the 2011, 2012 and 2013 growing seasons, canopy reflectance measurements were collected on cloud-free days using a full range (350-2500 nm) HR-1024 spectroradiometer (Spectra Vista Corporation, New York, NY, USA). The canopy spectra were taken from an elevated position between the rows at an average height of one meter above the top of the canopy ( $25^{\circ}$ field of view). The experimental setup is shown in Figure 1C. Within this field of view, some within-canopy shadow and background will always be present (Figure 1D). However, all measurements were taken after full canopy disclosure to negate fractional cover differences and to minimize the effect of noise from shadow and/or background inclusion. Between plots, instruments were calibrated with a Spectralon reference panel. For each plot, 5-8 sunlit canopy spectra were taken and averaged per plot. To minimize differences with regards to solar geometry and illumination, all measurements were performed within $1.5 \mathrm{~h}$ from local solar noon. All spectra were smoothed using a 2nd order Savitsky-Golay filter with a window size of $21 \mathrm{~nm}$ [26].

\subsubsection{Environmental Data}

Daily precipitation ( $\mathrm{mm} /$ day) and ETo $(\mathrm{mm} /$ day) were recorded and calculated at monitoring stations located 10 and $5 \mathrm{~km}$ from the irrigated and rainfed orchard, respectively (Portal of the Flemish 
Water managers, www.waterinfo.be (visited on 27 February 2014)). Average daily amount of rain deficit (or surplus) was calculated based on cumulative differences of precipitation and ETo [27,28]. To account for data gaps and measurement errors, the precipitation and ETo data from both monitoring stations was averaged on a daily basis prior to the calculation of cumulative available water.

\subsection{Data Analysis}

The spectral measurements (Section 2.2.2) were related to yield and quality variables (Section 2.2.1) through vegetation indices. The vegetation indices were chosen because of their proven relationship with water status and plant health in various agricultural crops and orchards. Moreover, the vegetation indices were associated either directly or indirectly with fruit yield and quality in horticultural crops $[12,13,15]$.

The Normalized Difference Water Index (NDWI; Equation (1)) [29], was applied because of the association with canopy water status [29]. This resulted in a direct correlation between canopy water status and production variables or an indirect correlation between NDWI values and fruit yield and quality $[12,16]$.

The Red-edge Normalized Difference Vegetation Index (ReNDVI; Equation (2)) [24], a normalized difference ratio between the NIR (Near-Infrared; 770-895 nm) and Red-edge (705-745 nm), was applied as it was previously related to water status (i.e., stem water potential) and plant health in irrigated and rainfed pear orchards [24]. This association could provide significant correlations with fruit yield and quality [1,22]. The spectral bands used for ReNDVI were calculated based on the WorldView-2 spectral response function [30,31], similar to [24].

The Photochemical Reflectance Index (PRI; Equation (3)) [32] was applied because of the association with plant photosynthetic activity and water status and the proven relationship with fruit yield and quality in horticulture $[13,19,33]$.

$$
\begin{gathered}
\text { NDWI }=\left(\mathrm{R}_{860}-\mathrm{R}_{1240}\right) /\left(\mathrm{R}_{860}+\mathrm{R}_{1240}\right) \\
\text { ReNDVI }=\left(\mathrm{R}_{\text {Near Infrared }}-\mathrm{R}_{\text {Red-edge }}\right) /\left(\mathrm{R}_{\text {Near Infrared }}+\mathrm{R}_{\text {Red-edge }}\right) \\
\text { PRI }=\left(\mathrm{R}_{531}-\mathrm{R}_{570}\right) /\left(\mathrm{R}_{531}+\mathrm{R}_{570}\right)
\end{gathered}
$$

with $R_{x}$ the reflectance at wavelength or band $x$.

The temporal variation of the correlation between spectral information and production variables (Section 2.2.1) was investigated. The correlation was analyzed at four key moments in the growing season coinciding with phenological stages of fruit development as specified through the BBCH code (Biologische Bundesanstalt, Bundessortenamt und CHemische Industrie) [34]. The considered phenological stages were fruitlet stage ( \pm 90 days before harvest or $\mathrm{BBCH} 71-72)$, end of fruit fall ( \pm 60 days before harvest or $\mathrm{BBCH} 73$ ), fruit ripening ( \pm 30 days before harvest or $\mathrm{BBCH} 81$ ) and harvest stage $(\mathrm{BBCH} 87)$. For each fruit development stage, the nearest spectral measurement was selected. Only measurements prior to harvest were used because of the significant change of canopy reflectance after harvest. The strength of correlation between vegetation indices and production variables was determined with the Pearson correlation coefficient (r). 


\section{Results}

\subsection{Environmental Conditions}

The gradient of cumulative rain deficit from 2011 to 2013 (Section 2.2.3), shown in Figure 2, highlights the differences between the monitored growing seasons. Note that in 2011, a dry spring (DOY 150-200) caused significant rain deficiencies, which could have affected fruit cell division. Oppositely, in 2012 a wet spring and summer caused rain surplus throughout the fruit cell division and vegetative growth period (DOY 100-200 or 150-50 days before harvest). In 2013, a rain surplus was present until 100 days before harvest (DOY 150) or the beginning of Stage II of fruit development, which is mostly associated with vegetative growth [3]. Subsequently, rain deficit steadily decreased towards the harvest period. Overall, the yearly precipitation was below the average precipitation of the last decade (i.e., $622 \pm 100 \mathrm{~mm}$ ) in $2011(546 \mathrm{~mm})$ and $2013(572 \mathrm{~mm})$. In 2012, the yearly precipitation $(711 \mathrm{~mm})$ was above the 10 -year-average.

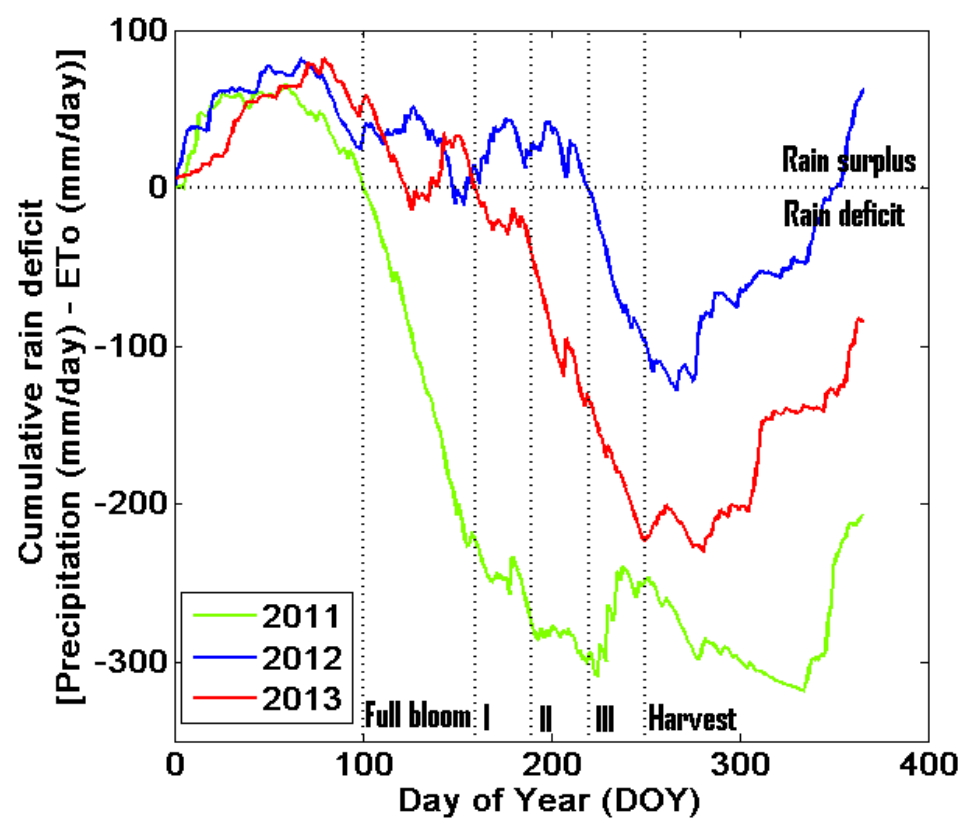

Figure 2. Cumulative rain deficit based on precipitation $(\mathrm{mm} /$ day) and ETo $(\mathrm{mm} /$ day $)$ from 2011 to 2013 (Section 2.2.3). Vertical dotted lines indicate the approximate dates of full bloom, fruitlet stage (I), end of fruit fall (II), fruit ripening (III) and harvest.

\subsection{Fruit Yield and Fruit Quality}

An overview of the quantitative - total yield per tree and number of fruits per tree - and qualitative production variables - fruit firmness, total soluble solids, chroma and hue - is given in Table 1. Overall, the production in the irrigated orchard was more stable throughout the three growing seasons compared to the rainfed orchard. This was visible in the number of fruits per tree, the standard deviation of yield (kg/tree) and the relative differences between growing seasons. The rainfed orchard presented lower yields per tree in a dry season (2011; Figure 2), while the irrigated orchard had a more stable yield (i.e., number of fruits) and improved fruit quality. 
Table 1. Overview of quantitative (i.e., total yield per tree and number of fruits per tree) and qualitative production variables after storage (i.e., firmness, total soluble solids (TSS), chroma and hue) in the irrigated and rainfed orchard for 2011-2013 ( \pm standard deviation). Values were averaged over 16 plots (eight plots in 2011 for the rainfed orchard).

\begin{tabular}{cccccccc}
\hline Location & Year & $\begin{array}{c}\text { Total Yield } \\
(\mathbf{k g} / \text { Tree })\end{array}$ & $\begin{array}{c}\text { Number of } \\
\text { Fruits per Tree }\end{array}$ & $\begin{array}{c}\text { Firmness } \\
\left(\mathbf{k g} / \mathbf{0 . 5} \mathbf{~ c m}^{2}\right)\end{array}$ & TSS $\left({ }^{\circ}\right.$ Brix $)$ & Chroma $\left({ }^{\circ}\right)$ & Hue $\left({ }^{\circ}\right)$ \\
\hline \multirow{2}{*}{$\begin{array}{l}\text { Irrigated } \\
\text { Orchard }\end{array}$} & 2011 & $28.4( \pm 3.1)$ & $159( \pm 16)$ & $5.7( \pm 0.4)$ & $11.7( \pm 0.6)$ & $41.5( \pm 1.5)$ & $111.0( \pm 0.8)$ \\
\cline { 2 - 8 } & 2012 & $17.5( \pm 3.0)$ & $108( \pm 27)$ & $7.0( \pm 0.2)$ & $12.5( \pm 0.4)$ & $41.2( \pm 0.6)$ & $109.9( \pm 0.4)$ \\
\hline \multirow{2}{*}{$\begin{array}{l}\text { Rainfed } \\
\text { Orchard }\end{array}$} & 2013 & $19.1( \pm 2.9)$ & $140( \pm 33)$ & $7.3( \pm 0.3)$ & $13.1( \pm 0.6)$ & $38.3( \pm 0.9)$ & $109.1( \pm 0.8)$ \\
\cline { 2 - 8 } & 2011 & $15.1( \pm 5.3)$ & $90( \pm 32)$ & $5.8( \pm 0.1)$ & $13.2( \pm 0.2)$ & $40.6( \pm 1.3)$ & $108.1( \pm 1.7)$ \\
\hline
\end{tabular}

\subsection{Production versus Spectral Measurements}

The temporal profile of the measured vegetation indices is shown in Figure 3. Overall, the measured vegetation indices were less variable in the irrigated orchard throughout the different growing seasons. This was visible through the smaller standard deviations between measured plots and the smaller differences between growing seasons.
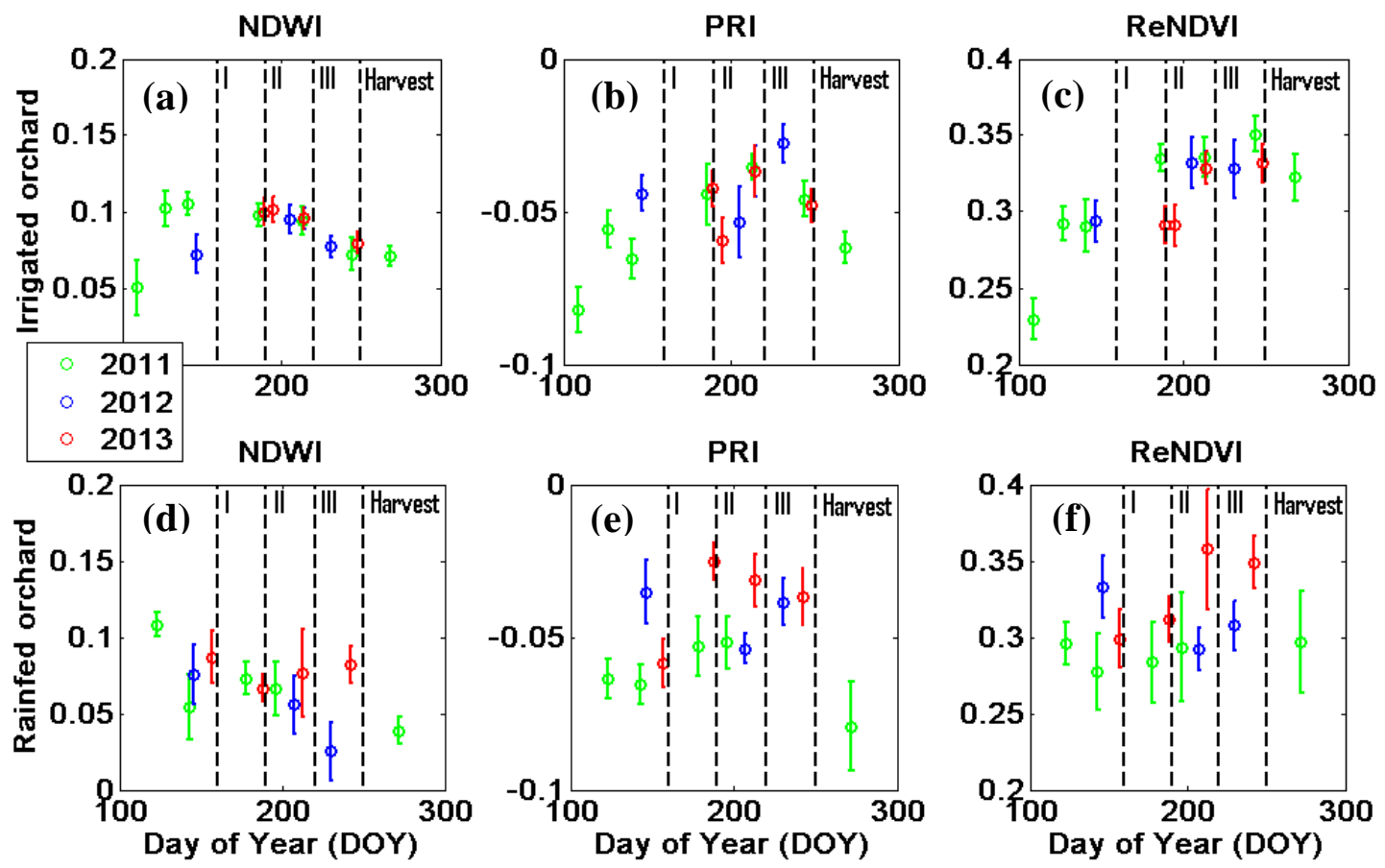

Figure 3. Profile of the Normalized Difference Water Index (NDWI; a); the Photochemical Reflectance Index (PRI; b) and the Red-edge Normalized Difference Vegetation Index (ReNDVI; c) for the irrigated orchard throughout each growing season and profile of NDWI (d), PRI (e) and ReNDVI (f) for the rainfed orchard throughout each growing season. Bars represent the standard deviation between all the measured plots and vertical dashed lines indicate approximate dates of phenological stages of fruit development, namely fruitlet stage (I), end of fruit fall (II), fruit ripening (III) and harvest. 
The temporal change of the correlation between spectral information (Section 2.3) and production variables (Section 2.2.1) was investigated at four moments in the growing season (i.e., fruitlet stage, end of fruit fall, fruit ripening and harvest). The results are presented in Table 2. The relationship between spectral vegetation indices and a selection of production variables - providing a complete set of vegetation indices, phenological stages and production variables - is highlighted for the irrigated orchard in Figure 4 and for the rainfed orchard in Figure 5.

Table 2. Pearson correlation coefficient (r) values between production variables (i.e., Total Yield, Number of fruits per tree, Fruit Firmness, Total Soluble Solids (TSS), Chroma and Hue) and the Normalized Difference Water Index (NDWI), the Photochemical Reflectance Index (PRI) and the Red-Edge Normalized Difference Vegetation Index (ReNDVI) respectively, for the irrigated and rainfed orchard throughout the growing season. The correlation was considered at four phenological stages in fruit development, namely fruitlet stage ( \pm 90 days before harvest), end of fruit fall ( \pm 60 days before harvest), fruit ripening ( \pm 30 days before harvest) and harvest. For each phenological stage the closest spectral measurements prior to harvest was chosen. Symbols indicated significance of correlation. Bold values point out correlations that are depicted in scatter plots in the following paragraphs.

\begin{tabular}{|c|c|c|c|c|c|c|c|c|c|}
\hline & & \multicolumn{4}{|c|}{ Total Yield (kg/tree) } & \multicolumn{4}{|c|}{ Number of Fruits per Tree } \\
\hline \multicolumn{2}{|c|}{ Phenological stage } & Fruitlet & $\begin{array}{c}\text { End of } \\
\text { fruit fall }\end{array}$ & $\begin{array}{c}\text { Fruit } \\
\text { ripening }\end{array}$ & Harvest & Fruitlet & $\begin{array}{c}\text { End of } \\
\text { fruit fall }\end{array}$ & $\begin{array}{c}\text { Fruit } \\
\text { ripening }\end{array}$ & Harvest \\
\hline \multirow{3}{*}{$\begin{array}{l}\text { Irrigated } \\
\text { Orchard }\end{array}$} & NDWI & $0.56^{* *}$ & 0.19 & 0.22 & $0.73^{* * *}$ & 0.53 ** & 0.11 & 0.06 & $0.47 * *$ \\
\hline & PRI & $-0.70^{* *}$ & -0.02 & $-0.41^{* *}$ & $-0.50 * *$ & $-0.33^{*}$ & 0.01 & -0.05 & $-0.49 * *$ \\
\hline & ReNDVI & 0.12 & -0.09 & $-0.30 *$ & $-0.37 * *$ & 0.21 & -0.26 & -0.13 & $-0.31 *$ \\
\hline \multirow{4}{*}{$\begin{array}{l}\text { Rainfed } \\
\text { Orchard }\end{array}$} & NDWI & $0.48 * *$ & 0.12 & $0.59^{* *}$ & $0.59^{* *}$ & $0.43 * *$ & 0.04 & $0.64 * *$ & $0.64 * *$ \\
\hline & PRI & -0.18 & $0.70 * *$ & 0.28 & 0.28 & $-0.31 *$ & $0.67 * *$ & 0.18 & 0.18 \\
\hline & ReNDVI & -0.02 & $0.66 * *$ & $0.65^{* * *}$ & $0.65^{* * *}$ & -0.18 & $0.60 * *$ & $0.56 * *$ & $0.56 * *$ \\
\hline & & \multicolumn{4}{|c|}{ * Significance at $p<0.05$} & \multicolumn{4}{|c|}{$* *$ Significance at $p<0.001$} \\
\hline & & \multicolumn{4}{|c|}{ Firmness $\left(\mathrm{kg} / 0.5 \mathrm{~cm}^{2}\right)$} & \multicolumn{4}{|c|}{ TSS ( ${ }^{\circ}$ brix) } \\
\hline \multicolumn{2}{|c|}{ Phenological stage } & Fruitlet & $\begin{array}{c}\text { End of } \\
\text { fruit fall }\end{array}$ & $\begin{array}{c}\text { Fruit } \\
\text { ripening }\end{array}$ & Harvest & Fruitlet & $\begin{array}{l}\text { End of } \\
\text { fruit fall }\end{array}$ & $\begin{array}{c}\text { Fruit } \\
\text { ripening }\end{array}$ & Harvest \\
\hline \multirow{3}{*}{$\begin{array}{l}\text { Irrigated } \\
\text { Orchard }\end{array}$} & NDWI & $-0.37^{* *}$ & -0.12 & -0.18 & $-0.69 * *$ & -0.22 & -0.11 & -0.24 & $-0.62 * *$ \\
\hline & PRI & $0.79 * *$ & -0.13 & $0.45^{* *}$ & 0.25 & $0.53 * *$ & -0.06 & $0.59 * *$ & 0.16 \\
\hline & ReNDVI & 0.06 & -0.21 & 0.21 & 0.24 & -0.22 & -0.21 & 0.26 & 0.24 \\
\hline \multirow{4}{*}{$\begin{array}{l}\text { Rainfed } \\
\text { Orchard }\end{array}$} & NDWI & 0.23 & 0.07 & -0.25 & -0.25 & -0.02 & 0.04 & $0.59 * *$ & $0.59 * *$ \\
\hline & PRI & $0.34 *$ & -0.01 & 0.21 & 0.21 & $-0.63 * *$ & $0.37 *$ & -0.13 & -0.13 \\
\hline & ReNDVI & 0.35 * & 0.15 & 0.07 & 0.07 & $-0.58 * *$ & 0.23 & 0.31 & 0.31 \\
\hline & & \multicolumn{4}{|c|}{${ }^{*}$ Significance at $p<0.05$} & \multicolumn{4}{|c|}{${ }^{* *}$ Significance at $p<0.001$} \\
\hline & & \multicolumn{4}{|c|}{ Chroma $\left(^{\circ}\right)$} & \multicolumn{4}{|c|}{ Hue $\left(^{\circ}\right)$} \\
\hline \multicolumn{2}{|c|}{ Phenological stage } & Fruitlet & $\begin{array}{c}\text { End of } \\
\text { fruit fall }\end{array}$ & $\begin{array}{c}\text { Fruit } \\
\text { ripening }\end{array}$ & Harvest & Fruitlet & $\begin{array}{c}\text { End of } \\
\text { fruit fall }\end{array}$ & $\begin{array}{c}\text { Fruit } \\
\text { ripening }\end{array}$ & Harvest \\
\hline \multirow{3}{*}{$\begin{array}{l}\text { Irrigated } \\
\text { Orchard }\end{array}$} & NDWI & -0.25 & -0.07 & 0.03 & $0.29 *$ & 0.23 & 0.12 & $0.35 *$ & $0.60 * *$ \\
\hline & PRI & $-0.47^{* *}$ & 0.18 & $-0.55 * *$ & 0.19 & $-0.62 * *$ & 0.14 & $-0.55 * *$ & -0.15 \\
\hline & ReNDVI & 0.11 & $0.51 * *$ & -0.21 & -0.20 & -0.03 & 0.25 & $-0.38^{* *}$ & -0.30 * \\
\hline \multirow{4}{*}{$\begin{array}{l}\text { Rainfed } \\
\text { Orchard }\end{array}$} & NDWI & $-0.44^{* *}$ & $-0.44 * *$ & $-0.66 * *$ & $-0.66^{* *}$ & -0.19 & -0.09 & $-0.53^{* *}$ & $-0.53^{* *}$ \\
\hline & PRI & $0.53 * *$ & $-0.71 * *$ & -0.26 & -0.26 & $0.59 * *$ & $-0.53^{* *}$ & 0.06 & 0.06 \\
\hline & ReNDVI & $0.40 *$ & $-0.73 * *$ & $-0.79 * *$ & $-0.79 * *$ & $0.58 * *$ & $-0.45^{* *}$ & $-0.35^{*}$ & $-0.35^{*}$ \\
\hline & & \multicolumn{4}{|c|}{${ }^{*}$ Significance at $p<0.05$} & \multicolumn{4}{|c|}{$* *$ Significance at $p<0.001$} \\
\hline
\end{tabular}


In the irrigated orchard, the correlation between vegetation indices and production variables was dependent on the phenological stage. Spectral indices were associated to production variables in the beginning of the growing season (fruitlet stage) and towards the harvest. For almost all production variables, a significant drop was noticeable at the end of fruit fall ( \pm 60 days before harvest) compared to the rest of the growing season. This was illustrated between TSS and PRI values at the end of fruit fall (Figure 4c) and during fruit ripening (Figure 4d). NDWI values showed a positive correlation with production quantity (i.e., total yield and number of fruits per tree) and a negative correlation with quality-related production variables (i.e., firmness and TSS). Conversely, PRI and ReNDVI values displayed a negative correlation with production quantity and a negative with production quality. This was illustrated for both total yield (Figure 4a) and firmness (Figure 4b) combined with NDWI values at harvest. Furthermore, spectral indicators for color characteristics showed a similar gradient to quantity related variables, with a positive correlation with NDWI values and a negative correlation with PRI and ReNDVI values.
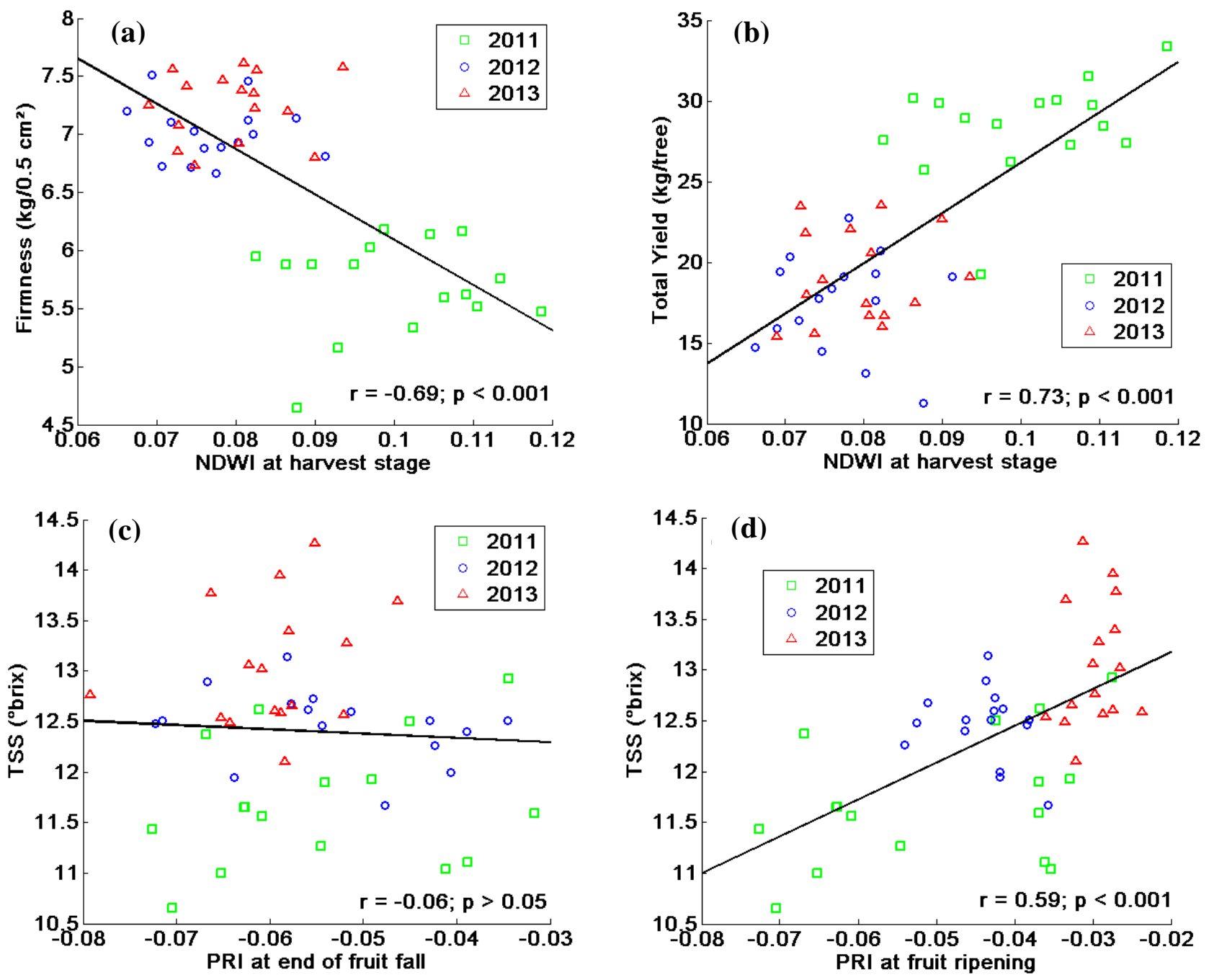

Figure 4. Cont. 

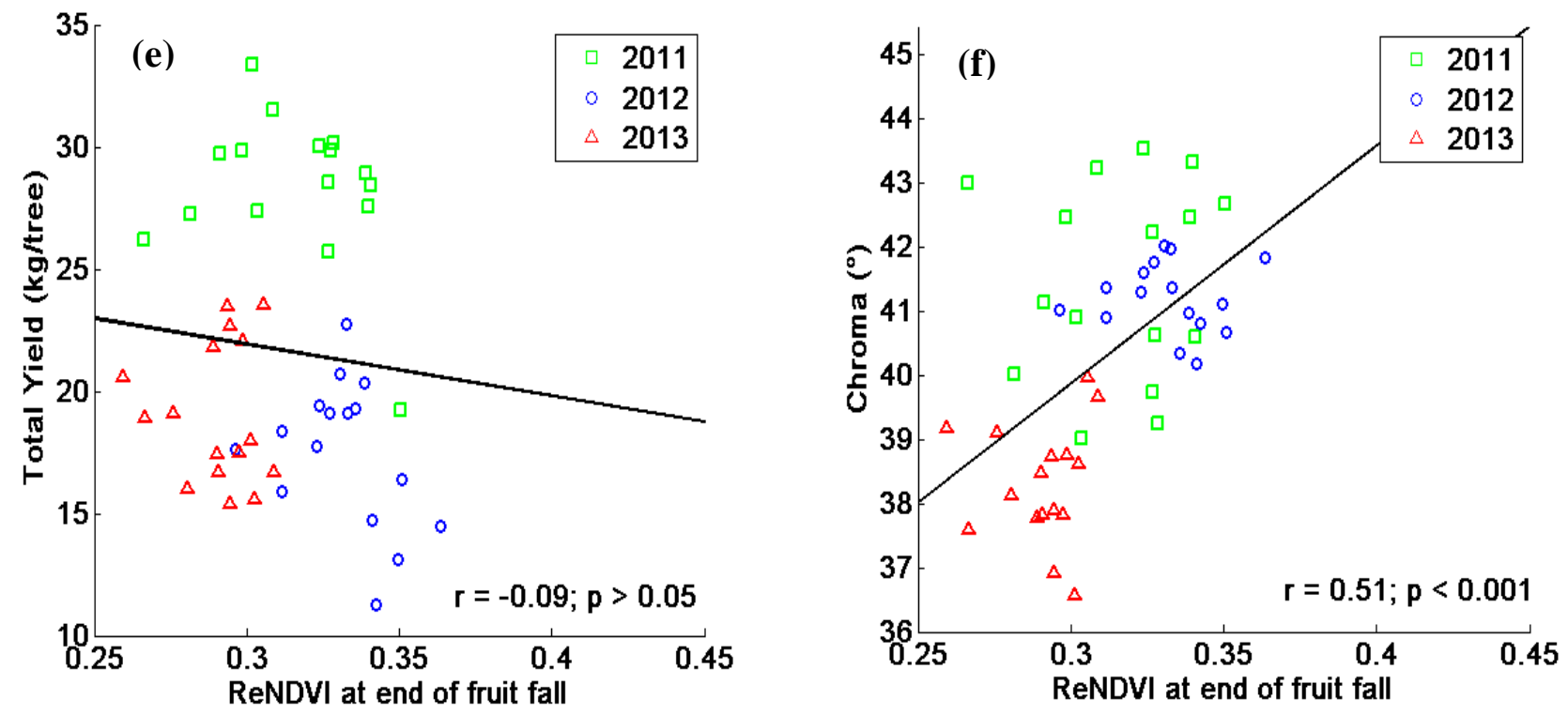

Figure 4. Scatter plots at various stages in the growing season between spectral vegetation indices, namely the Normalized Difference Water Index (NDWI; a,b), the Photochemical Reflectance Index (PRI; c,d) and the Red-edge Normalized Difference Vegetation Index (ReNDVI; e,f) and production variables, namely Fruit Firmness (a), Total Yield (b,f), Total Soluble Solids (TSS; c,d) and Chroma (e) in the irrigated orchard. All points were labeled for growing season.

Similar to the irrigated orchard, the correlation between vegetation indices and production variables in the rainfed orchard was not constant throughout the growing season. For PRI values, the end of fruit fall ( \pm 60 days before harvest) showed significantly higher correlations $(\mathrm{r}>0.6 ; p<0.001)$ with quantity-related production variables compared to the rest of the growing season (Figure 5c). Similarly, ReNDVI values at the end of fruit fall were significantly correlated with quantity-related production variables (Figure 5f). Conversely to PRI values, the remainder of the growing season also presented high correlation coefficients $(\mathrm{r}>0.56 ; p<0.001)$. NDWI values were more related to both quantity and quality-related production variables towards the end of the growing season $(|\mathrm{r}| \approx 0.6$; $p<0.001$ ). This is illustrated for TSS and NDWI values at fruitlet (Figure 5a) and fruit ripening stages (Figure 5b).

In the rainfed orchard, spectral indices were more associated with color variables compared to firmness and TSS values. This is illustrated for PRI values at fruitlet stage and hue data (Figure 5d) and ReNDVI values at the end of fruit fall and chroma data (Figure 5e). However, in contrast with the irrigated orchard (Figure 4e), the correlation between spectral indices and color variables-chroma and hue-presented the reverse gradient compared to yield (Figure 5d,e). 

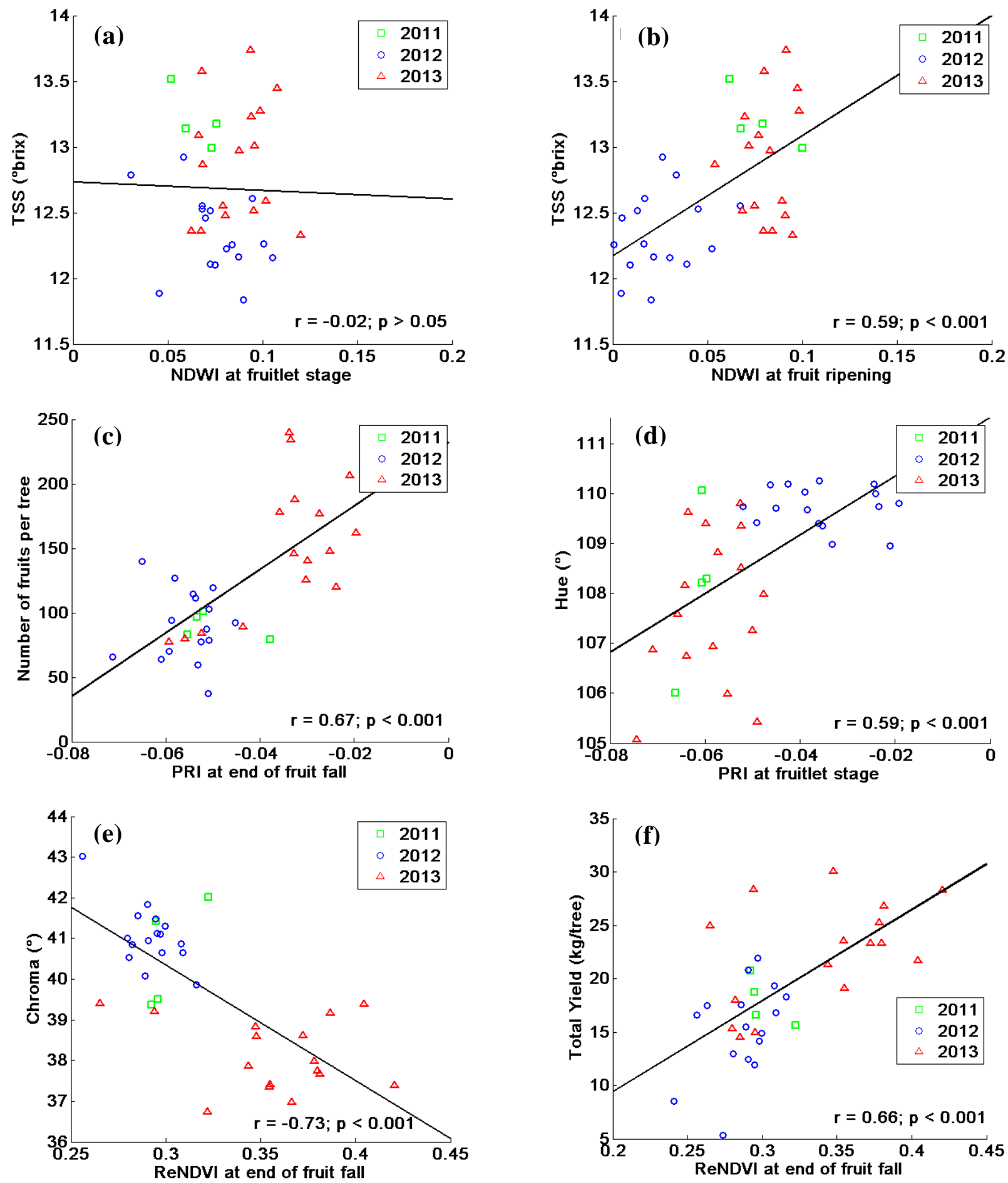

Figure 5. Scatter plots at various stages in the growing season between spectral vegetation indices, namely the Normalized Difference Water Index (NDWI; a,b), the Photochemical Reflectance Index (PRI; c,d) and the Red-edge Normalized Difference Vegetation Index (ReNDVI; e,f) and production variables, namely Total Soluble Solids (TSS; a,b); Number of fruits per tree (c); Hue (d); Chroma (e) and Total Yield (f) in the rainfed orchard. All points were labeled for growing season. 


\section{Discussion}

\subsection{Production versus Spectral Measurements}

In general, Figure 2 and Table 1 illustrated the diversity of the growing conditions during the study. In these diverse conditions, remote sensing information was found to be associated with production variables and could provide agricultural managers with a reliable estimation of quantitative $(|\mathrm{r}|>0.6$; $p<0.001)$ and qualitative production variables $(|\mathrm{r}|>0.7 ; p<0.001)$ prior to harvest. Upon comparison to previous studies, the $r$ values between vegetation indices at harvest and quantity-related production variables in this study were similar or higher. For instance, $|\mathrm{r}|$ values between 0.3 and 0.7 (Table 2) compared to $|\mathrm{r}|$ values of 0.6 for water related indices in vineyards [16] and between 0.2 and 0.6 for PRI in citrus orchards [13]. With regards to quality-related production variables, the association with vegetation indices yielded comparable $r$ values as other studies. An $|r|$ value of 0.41 was found between TSS and PRI values 45 days before harvest (i.e., between end of fruit fall and fruit ripening) in citrus orchards [19]. In vineyards, TSS was associated to water content related indices at harvest $(|\mathrm{r}|$ value of 0.5) [16]. Similarly to Serrano et al. [16], this study showed that water related indices (i.e., NDWI), plant health (i.e., ReNDVI) and plant photosynthetic activity indices (i.e., PRI) were related to total yield per tree and to fruit quality (Table 2). However, the choice of vegetation index was important, as the temporal dependence of these correlations was variable for different vegetation indices and between orchards (Figures 4 and 5 and Table 2).

The differences between the irrigated and rainfed orchard could be attributed to the differences in water availability at critical stages in the growing season (Figure 2), but could also be the result of differences in vigor for the different rootstocks [35] and training systems. In the rainfed orchard, the relationships between vegetation indices and production variables were more variable throughout the growing season. The absence of irrigation during dry periods possibly increased the influence of environmental conditions on TSS and fruit firmness (i.e., water availability [36], amount of sunlight [37] and daily temperature [38]) and resulted in a variable correlation throughout the growing season (Figure $5 \mathrm{c}, \mathrm{b}$ ). The correlation between ReNDVI values and production variables was highly variable between both orchards (Figure 4e and Figure 5f). This might be caused by the underlying relationship with stem water potential [24]. As a result of the deficit irrigation treatment in the irrigated orchard, large stem water potential differences were maintained during the end of fruit fall without significant fruit yield and fruit quality differences because of the ability to irrigate in later stages of fruit development. In the rainfed orchard, the potential stem water differences caused by the root pruning treatment would result in increased water deficiency [39] which in turn led to decreased fruit yield and improved fruit quality [27]. A similar trend was also visible for PRI values because of the association with stem water potential [40].

The correlation between vegetation indices and production variables was more stable throughout the growing season in the irrigated orchard, because of the possibility to irrigate during dry periods. This was also visible for the spectral vegetation indices (Figure 3), which were more stable towards the end of the growing season compared to the rainfed orchard. During the deficit irrigation period $(\approx$ end of fruit fall), large differences were achieved without significant fruit yield and fruit quality differences because of the ability to irrigate in later stages of fruit development. Therefore, the optimal period for 
remote sensing measurements in irrigated orchards would be before or after the vegetative growth period (i.e., less than 30 days before harvest; Figure 5a,b,d), as small spectral differences would not result in variable fruit yield and quality in the vegetative growth period (Figure 5c). Measurements in the rainfed orchard at the end of fruit fall-associated with minimized fruit growth and more vegetative growth [3,23] - provided a good estimation of production quantity through ReNDVI $(\mathrm{r}=0.66 ; p<0.001$; Figure 5f) and PRI $(\mathrm{r}=0.67 ; p<0.001$; Figure 5c). Oppositely, water availability differences had a larger impact on the total production towards the end of the growing season, which resulted in higher $|\mathrm{r}|$ values between total yield and NDWI $(\mathrm{r} \approx 0.6 ; p<0.001$; Table 2$)$.

\subsection{Potential and Limitations}

With the use of remote sensing, the estimation or prediction of production and visualization of optimal monitoring periods could be determined (Table 2 and Figures 4 and 5). This would allow remote sensing to visualize the large spatial variability (>20 kg/tree) $[4,5]$ present within each orchard and optimize and schedule management procedures - deficit irrigation [27], summer pruning [39], root pruning [39], fruit thinning [41], fertigation [42] and harvest - throughout the growing season to improve production quality and yield [7]. However, several limitations remain with the use of remote sensing for the estimation of the orchards' production potential.

Although the results indicated a good correlation between spectral measurements and production variables, this relationship was dependent on the growing season (Figures 4 and 5). This was the result of highly variable weather conditions (Figure 2). Moreover, the alternate bearing tendency of some horticultural crops could cause large differences in subsequent growing seasons [13]. In this study, some alternate bearing was present (Table 1), especially in the rainfed orchard. However, the effect was smaller compared to other studies [13] because of the parthenocarpic tendency of Conference pears and the lack of return bloom inhibition by seeds [43]. Larger time series could provide more stable estimations of fruit yield and fruit quality because of the link between climatic differences and production potential. Moreover, larger time series would also provide information on the reliability of remote sensing data during each phenological stage in the growing season.

Conversely to annual crops [9-11], the significant correlations between vegetation indices and production variables were not the result of a direct relation between above ground biomass and crop yield [44]. The present season's growing conditions have a smaller impact compared to annual crops, as the amount of fruit buds (i.e., production potential) is influenced by crop load [45] and the plants' water status $[27,39,46]$ of the previous growing season [1]. The correlation between production variables and vegetation indices most likely stemmed from the association with vegetative growth and the relationship between vegetative growth, water status and production $[14,47,48]$. Trees with more vegetative growth produced less flower buds (i.e., decreased number of fruits and total yields), as a result of the considerable consumption of water from excessive vegetative growth [47]. The spectral vegetation indices provided an overall indication of plant health - plant vigor [24], water content [24,29,32], photosynthetic efficiency [32] — which in turn was related to production variables. Because of the indirect nature of this relationship, several periods within the growing season showed insignificant correlation between vegetation indices and production variables (Figures $4 \mathrm{a}$ and $5 \mathrm{a}$ ). 
One of the difficulties with production estimation in orchards is the trade-off between fruit yield and fruit quality $[16,28,36,42,49]$. This link between fruit quality and quantity was also visible in the irrigated orchard (Table 1; Figure 4a,b; Figure 5e,f). For PRI values, a positive correlation was present with fruit firmness and TSS and a negative correlation was found with total yield, similarly to Serrano et al. [16]. Overall, a healthier tree in the irrigated orchard (i.e., higher PRI values) produced better quality fruit, while increased water availability (i.e., higher NDWI values) increased fruit yield. In the rainfed orchard, a healthier tree (i.e., higher PRI values) and increased water availability (i.e., higher NDWI values) both led to the production of more fruits with lower fruit quality (i.e., yellowing of fruit) [36].

In this study, the relationship between vegetation indices and production variables was shown to differ between irrigated and rainfed orchards (Figures 4 and 5 and Table 2), as a result of water availability and rootstock differences [35]. Although this might obstruct practical use of prediction models over larger areas, previous studies in orchard crops could distinguish irrigated from rainfed orchards [50]. As a result, the analysis could be adjusted based on these methodologies or through cooperation with fruit growers. Ultimately, the production estimates from remote sensing could only provide an indication of the production potential, as extreme conditions or circumstances - storms, hail or bird damage - could damage the crops. On the other hand, with the incorporation of environmental conditions into crop models, further improvement of horticultural production estimation and management should be achievable.

\section{Conclusions}

Remote sensing provides an alternative to time consuming, labor intensive and destructive in situ measurements required for yield and quality monitoring and estimation. In this study, an irrigated and a rainfed orchard were monitored with hyperspectral sensors through three subsequent growing seasons, demonstrating the potential of spectral measurements for the prediction of quality-fruit firmness and total soluble solids - and quantity-related production properties - total yield and amount of fruits per tree - throughout the growing season.

The results illustrated an association between vegetation indices - the Normalized Difference Water Index (NDWI), the Photochemical Reflectance Index (PRI) and Red-edge Normalized Difference Vegetation Index (ReNDVI) — and both fruit yield and fruit quality variables $(|\mathrm{r}|>0.6 ; p<0.001)$. However, the relationship between spectral indicators and production variables was variable throughout the growing season and between orchards. This temporal dependency demonstrated the usefulness of remote sensing and the necessity of optimized scheduling and interpretation of the results. In the rainfed orchard, NDWI values at harvest showed a positive correlation with yield $(\mathrm{r} \approx 0.6$; $p<0.001$ ), while PRI and ReNDVI values at the end of fruit fall ( \pm 60 days before harvest) were strongly related to yield $(\mathrm{r}>0.6 ; p<0.001)$. In the irrigated orchard, PRI values near harvest showed a positive correlation with fruit firmness and TSS $(\mathrm{r} \approx 0.5 ; p<0.001)$, while NDWI values showed the reverse gradient $(\mathrm{r} \approx-0.6 ; p<0.001)$ and ReNDVI values showed no significant correlation. At the end of fruit fall — characterized by vegetative growth ( \pm 60 days before harvest) — vegetation index values in the irrigated orchard were not correlated with yield and fruit quality. 
Despite diverse conditions, remote sensing technology was able to correlate with production variables and could provide fruit growers with a reliable estimation of their production quantity $(|\mathrm{r}|>0.7 ; p<0.001)$ and quality $(|\mathrm{r}|>0.7 ; p<0.001)$ for several periods in the growing season. The results in this study highlighted the necessity of the careful use and selection of vegetation indices and monitoring times. Overall, these indices could enable managers to predict fruit yield and quality several months prior to harvest, allowing for optimized scheduling of management processes, such as deficit irrigation, hand thinning, fertigation and fruit harvest.

\section{Acknowledgments}

This work was supported by the Agency for Innovation by Science and Technology in Flanders (IWT-Vlaanderen). The research was funded through a project in collaboration with the Soil Service of Belgium (BDB) and the Research Center for Fruit (Proefcentrum Fruitteelt in Sint-Truiden). The authors would like to thank fruit grower Jan Vandervelpen for allowing research in his orchard and making this work possible.

\section{Author Contributions}

Experimental design: Jonathan Van Beek, Tom Deckers, Wim Verjans, Pieter Janssens and Pol Coppin; Data collection and processing: Jonathan Van Beek, Laurent Tits and Wim Verjans; Statistical analysis and interpretation: Jonathan Van Beek, Laurent Tits, Ben Somers, Tom Deckers and Pieter Janssens; Manuscript preparation, writing and paper review: Jonathan Van Beek, Laurent Tits, Ben Somers, Tom Deckers, Wim Verjans, Dany Bylemans, Pieter Janssens and Pol Coppin; Project coordination: Jonathan Van Beek, Tom Deckers, Dany Bylemans, Pieter Janssens and Pol Coppin.

\section{Conflicts of Interest}

The authors declare no conflict of interest.

\section{References}

1. Webster, A.D. Factors influencing the flowering, fruit set and fruit growth of European pears. In Acta Horticultura 569; ISHS: Leuven, Belgium, 2002; pp. 699-709.

2. Goodwin, I.; Boland, A.-M. Scheduling deficit irrigation of fruit trees for optimizing water use efficiency. In Deficit Irrigation Practices. Water Reports Publication n. 22; Food and Agriculture Organization (FAO): Rome, Italy, 2002; pp. 67-78.

3. Mitchell, P.D.; Chalmers, D.J.; Jerie, P.H.; Burge, G. The use of initial withholding of irrigation and tree spacing to enhance the effect of regulated deficit irrigation on pear trees. J. Am. Soc. Hortic. Sci. 1986, 111, 858-861.

4. Perry, E.M.; Dezzani, R.J.; Seavert, C.F.; Pierce, F.J. Spatial variation in tree characteristics and yield in a pear orchard. Precis. Agric. 2009, 11, 42-60.

5. Aggelopoulou, K.D.; Wulfsohn, D.; Fountas, S.; Gemtos, T.A.; Nanos, G.D.; Blackmore, S. Spatial variation in yield and quality in a small apple orchard. Precis. Agric. 2009, 11, 538-556. 
6. Dorigo, W.A.; Zurita-Milla, R.; de Wit, A.J.W.; Brazile, J.; Singh, R.; Schaepman, M.E. A review on reflective remote sensing and data assimilation techniques for enhanced agroecosystem modeling. Int. J. Appl. Earth Obs. Geoinf. 2007, 9, 165-193.

7. Usha, K.; Singh, B. Potential applications of remote sensing in horticulture-A review. Sci. Hortic. 2013, 153, 71-83.

8. Van Beek, J.; Tits, L.; Somers, B.; Deckers, T.; Janssens, P.; Coppin, P. Reducing background effects in orchards through spectral vegetation index correction. Int. J. Appl. Earth Obs. Geoinf. 2014, 34, 167-177.

9. Zarco-Tejada, P.J.; Ustin, S.L.; Whiting, M.L. Temporal and spatial relationships between within-field yield variability in cotton and high-spatial hyperspectral remote sensing imagery. Agron. J. 2005, 97, 641-653.

10. Thenkabail, P.S.; Ward, A.D.; Lyon, J.G. Landsat-5 thematic mapper models of soybean and corn crop characteristics. Int. J. Remote Sens. 1994, 15, 49-61.

11. Thenkabail, P.S.; Ward, A.D.; Lyon, J.G.; Merry, C.J. Thematic mapper vegetation indices for determining soybean and corn growth parameters. Photogramm. Eng. Remote Sens. 1994, 60, 437-442.

12. Somers, B.; Delalieux, S.; Verstraeten, W.W.; van den Eynde, A.; Barry, G.H.; Coppin, P. The contribution of the fruit component to the hyperspectral citrus canopy signal. Photogramm. Eng. Remote Sens. 2010, 76, 37-47.

13. Ye, X.; Sakai, K.; Manago, M.; Asada, S.; Sasao, A. Prediction of citrus yield from airborne hyperspectral imagery. Precis. Agric. 2007, 8, 111-125.

14. Best, S.; Salazar, F.; Bastías, R.; Leon, L. Crop load estimation model to optimize yield-quality ratio in Apple Orchards, Malus Domestica Borkh, Var. Royal Gala. J. Inf. Technol. Agric. 2008, $3,11-18$.

15. Sepulcre-Canto, G.; Zarco-Tejada, P.; Jimenez-Munoz, J.; Sobrino, J.; Soriano, M.; Fereres, E.; Vega, V.; Pastor, M. Monitoring yield and fruit quality parameters in open-canopy tree crops under water stress. Implications for ASTER. Remote Sens. Environ. 2007, 107, 455-470.

16. Serrano, L.; González-Flor, C.; Gorchs, G. Assessment of grape yield and composition using the reflectance based Water Index in Mediterranean rainfed vineyards. Remote Sens. Environ. 2012, $118,249-258$.

17. Gallardo, R.K.; Kupferman, E.; Colonna, A. Willingness to pay for optimal "Anjou” pear quality. Hortic. Sci. 2011, 46, 452-456.

18. Nicolaï, B.M.; Beullens, K.; Bobelyn, E.; Peirs, A.; Saeys, W.; Theron, K.I.; Lammertyn, J. Nondestructive measurement of fruit and vegetable quality by means of NIR spectroscopy: A review. Postharvest Biol. Technol. 2007, 46, 99-118.

19. Suárez, L.; Zarco-Tejada, P.J.; González-Dugo, V.; Berni, J.A.J.; Sagardoy, R.; Morales, F.; Fereres, E. Detecting water stress effects on fruit quality in orchards with time-series PRI airborne imagery. Remote Sens. Environ. 2010, 114, 286-298.

20. Hatfield, J.L.; Prueger, J.H. Value of using different vegetative indices to quantify agricultural crop characteristics at different growth stages under varying management practices. Remote Sens. 2010, 2, 562-578. 
21. Sansavini, S.; Musacchi, S. Canopy architecture, training and pruning in the modern European pear orchards: An overview. Acta Hortic. 1994, 367, 152-172.

22. Allen, R.G.; Pereira, L.S.; Raes, D.; Smith, M. Crop Evapotranspiration-Guidelines for Computing Crop Water Requirements-FAO Irrigation and Drainage Paper 56; FAO: Quebec City, QC, Canada, 1998.

23. Mitchell, P.D.; Jerie, P.H.; Chalmers, D.J. Effects of regulated water deficits on pear tree growth, flowering, fruit growth, and yield. J. Am. Soc. Hortic. Sci. 1984, 109, 604-606.

24. Van Beek, J.; Tits, L.; Somers, B.; Coppin, P. Stem water potential monitoring in pear orchards through WorldView-2 multispectral imagery. Remote Sens. 2013, 5, 6647-6666.

25. McGuire, R.G. Reporting of objective colour measurements. Hortic. Sci. 1992, 27, 1254-1255.

26. Savitsky, A.; Golay, M.J.E. Smoothing and differentiation of data by simplified least squares procedures. Anal. Chem. 1964, 36, 1627-1639.

27. Janssens, P.; Deckers, T.; Elsen, F.; Elsen, A.; Schoofs, H.; Verjans, W.; Vandendriessche, H. Sensitivity of root pruned "Conference" pear to water deficit in a temperate climate. Agric. Water Manag. 2011, 99, 58-66.

28. Alcobendas, R.; Mirás-Avalos, J.M.; Alarcón, J.J.; Pedrero, F.; Nicolás, E. Combined effects of irrigation, crop load and fruit position on size, color and firmness of fruits in an extra-early cultivar of peach. Sci. Hortic. 2012, 142, 128-135.

29. Gao, B. NDWI a normalized difference water index for remote sensing of vegetation liquid water from space. Remote Sens. Environ. 1996, 58, 257-266.

30. Updike, T.; Comp, C. Radiometric Use of WorldView-2 Imagery Technical Note; DigitalGlobe: Longmont, CO, USA, 2010.

31. Van Leeuwen, W.J.D.; Orr, B.J.; Marsh, S.E.; Herrmann, S.M. Multi-sensor NDVI data continuity: Uncertainties and implications for vegetation monitoring applications. Remote Sens. Environ. 2006, 100, 67-81.

32. Gamon, A.; Serrano, L.; Surfus, S. The photochemical reflectance index : An optical indicator of photosynthetic radiation use efficiency across species, functional types, and nutrient levels. Oecologia 1997, 112, 492-501.

33. Stagakis, S.; González-Dugo, V.; Cid, P.; Guillén-Climent, M.L.; Zarco-Tejada, P.J. Monitoring water stress and fruit quality in an orange orchard under regulated deficit irrigation using narrow-band structural and physiological remote sensing indices. ISPRS J. Photogramm. Remote Sens. 2012, 71, 47-61.

34. Meier, U.; Graf, H.; Hack, H.; Hess, M.; Kennel, W.; Klose, R.; Mappes, D.; Seipp, D.; Stauss, R.; Streif, J.; et al. Phaenologische entwicklungsstadien des Kernobstes (Malus domestica Borkh. und Pyrus communis L.), des Steinobstes (Prunus-Arten), der Johannisbeere (Ribes-Arten) und der Erdbeere (Fragaria x ananassa Duch.). Nachrichtenblatt Dtsch. Pflanzenschutzdienstes 1994, 46, 141-153.

35. Massai, R.; Loreti, F.; Fei, C.; Legnose, S. Growth and yield of "Conference" pears grafted on quince and pear rootstocks. Acta Hortic. 2008, 617-624.

36. Mpelasoka, B.S.; Behboudian, M.H.; Green, S.R. Water use, yield and fruit quality of lysimeter-grown apple trees: Responses to deficit irrigation and to crop load. Irrig. Sci. 2001, 20, 107-113. 
37. Barrit, B.H.; Konishi, B.S.; Drake, S.R.; Rom, C.R. Influence of sunlight level and rootstock on apple fruit quality. Acta Hortic. 1997, 451, 569-577.

38. Oke, A.M.C.C.; Tapper, N.J.; Barlow, E.W.R. Within-vineyard variability in grape quality and yield and its relationship to the vineyard environment. Acta Hortic. 2007, 754, 507-514.

39. Asin, L.; Alegre, S.; Montserrat, R. Effect deficit irrigation,sumer pruning and root pruning on shoot growth, yield, and return bloom, in a "Blanquilla" pear orchard. Sci. Hortic. 2007, 113, 142-148.

40. Suárez, L.; Zarco-Tejada, P.J.; Sepulcre-Cantó, G.; Pérez-Priego, O.; Miller, J.R.; Jiménez-Muñoz, J.C.; Sobrino, J. Assessing canopy PRI for water stress detection with diurnal airborne imagery. Remote Sens. Environ. 2008, 112, 560-575.

41. Treder, W. Crop loading studies with "Jonagold” Apple tree. J. Fruit Ornam. Plant Res. 2010, 18, 59-69.

42. Hudina, M.; Štampar, F. The correlation of the pear (Pyrus communis L.) cv. "Williams" yield quality to the foliar nutrition and water regime. Acta Agric. Slov. 2005, 85, 179-185.

43. Chan, B.G.; Cain, J.C. The effect of seed formation on subsequent flowering in apple. Proc. Am. Soc. Hortic. Sci. 1967, 91, 63-68.

44. Thenkabail, P.S.; Smith, R.B.; de Pauw, E. Evaluation of narrowband and broadband vegetation indices for determining optimal hyperspectral wavebands for agricultural crop characterization. Photogramm. Eng. Remote Sens. 2002, 68, 607-621.

45. Webster, A.D.; Spencer, J.E. New strategies for the chemical thinning of apple And, (Malus domestica Borkh.) cultivars Queen Cox and Royal Gala. J. Hortic. Sci. Biotechnol. 1999, 74, 337-346.

46. Marsal, J.; Arbone, A.; Rufat, J.; Girona, J. Regulated deficit irrigation and rectification of irrigation scheduling in young pear trees: An evaluation based on vegetative and productive response. Eur. J. Agronomy 2002, 17, 111-122.

47. Wu, Y.; Zhao, Z.; Wang, W.; Ma, Y.; Huang, X. Yield and growth of mature pear trees under water deficit during slow fruit growth stages in sparse planting orchard. Sci. Hortic. 2013, 164, 189-195.

48. Jung, S.-K.; Choi, H.-S. Light penetration, growth, and fruit productivity in "Fuji" apple trees trained to four growing systems. Sci. Hortic. 2010, 125, 672-678.

49. Naor, A. Irrigation and crop load influence fruit size and water relations in field-grown "Spadona" pear. J. Am. Soc. Hortic. Sci. 2001, 126, 252-255.

50. Sepulcre-Cantó, G.; Zarco-Tejada, P.J.; Sobrino, J.A.; Berni, J.A.J.; Jiménez-Muñoz, J.C.; Gastellu-Etchegorry, J.P. Discriminating irrigated and rainfed olive orchards with thermal ASTER imagery and DART 3D simulation. Agric. For. Meteorol. 2009, 149, 962-975.

(C) 2015 by the authors; licensee MDPI, Basel, Switzerland. This article is an open access article distributed under the terms and conditions of the Creative Commons Attribution license (http://creativecommons.org/licenses/by/4.0/). 